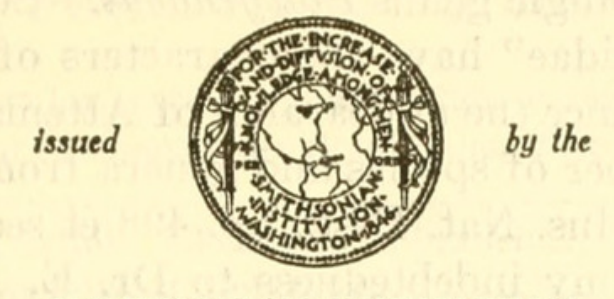

SMITHSONIAN INSTITUTION

U. S. NATIONAL MUSEUM

Washington; 1951

No. 3300

\title{
A NEW GENUS OF CENTRAL AMERICAN MILLIPED (FAMILY EURYURIDAE), WITH NOTES ON THE AMER- ICAN GENERA.
}

\section{By Richard L. HofFmaN}

While sorting out unidentified millipeds in the collection of the United States National Museum, I encountered a single male specimen that represents an unnamed genus (here described) of the family Euryuridae. Investigation of pertinent literature has revealed several taxonomic errors that may be corrected at this time, and it appears that at least one genus (Polylepiscus) is readily separable into two more natural groups.

Together with these various additions and emendations, I include new distributional records for two species of Amplinus, and a consideration of the known American euryurid genera with reference to some diagnostic characters whose value seems questionable. A tentative key to the genera is provided.

The Euryuridae is a small family (12 genera and about 50 species) with many of the characters of the Platyrrhacidae and with nearly the same distribution. Both families are represented in the Indo-Australian region and in tropical America; species of Euryurus and Auturus also invade the North Temperate Zone as far as Ohio and Minnesota.

The most recent, and only complete, account of the Euryuridae is to be found in Attems' monumental Polydesmoidea monograph (Das Tierreich, Lief. 68-70, 1937-1940). This manual lists all known species and because of its conservatism affords an excellent starting point for taxonomic studies. Attems combines the Euryuridae and 
Platyrrhacidae (Lief. 69, p. 202), the latter being represented in his arrangement by the single genus Platyrhacus. Seven other genera of Attems' "Platyrrhacidae" have the characters of the Euryuridae as here understood. ${ }^{1}$ Since the appearance of Attems' work, Chamberlin has described a number of species and genera from northeastern Peru (1941, Bull. Amer. Mus. Nat. Hist., pp. 498 et seq.).

I wish to express my indebtedness to Dr. E. A. Chapin, curator, division of insects, United States National Museum, who has greatly facilitated my work at that institution; to R. L. Wenzel, division of insects, Chicago Natural History Museum, for the loan of many specimens from collections under his charge; and to Dr. Clarence $\mathbf{J}$. Goodnight, department of biological sciences, Purdue University, who has kindly given me valuable material from his Central American collecting.

\section{REMARKS ON TAXONOMIC CHARACTERS}

Attems' key to the five American genera recognized by him is based to a considerable extent upon sculpture of the dorsum. Euryurus and Pycnotropis are separated off in couplet 4 by the statement "Metazoniten glatt oder nur mit Spuren einer polygonalen Felder," as opposed to "Metazoniten mit Querreihen grosser Tuberkeln," which leads to Polylepiscus and Amplinus.

This reliance upon tergite modification leads to considerable difficulty. Even in the four genera mentioned, one finds smooth species in "tuberculate" genera, and vice versa. The issue is complicated by the addition of Chamberlin's four Peruvian genera and one from Panama to be described herein. There seems to be such variability in the development of polygonal areas on the dorsum that its practical value is largely negated. The new Panamanian form keys out to Pycnotropis, and the gonopods are of the type found in that genus, but other characters are those of Phinotropis (Polylepiscus, in part, of Attems). Because of the difficulty attendant upon the use of sculpture, I believe it advisable to appeal to other characters, such as subantennal swellings, anal sternite, and male gonopods, for generic diagnosis.

The following key appears to be satisfactory at present for the recognition of American genera:

\footnotetext{
${ }^{1}$ The genus Aphelidesmus has been placed in the Euryuridae by recent American workers at one time or another, since the time of Cook (1895) and Pocock (1909). Despite its somewhat truncate terminal segment, Aphelidesmus properly belongs in the family Strongylosomidae, a group with somewhat distant affinitles.
} 
1. Anal sternite distally truncate, with two large setiferous tubercules.

Amplinus

Anal sternite semicircular, with very small tubercules or none

2. Male gonopod without solenomerite; tibiotarsus, if present, not set off from

femur

Male gonopod with a definite solenomerite branch

4

3. Gonopod without perceptible tibiotarsus

Auturus

Gonopod with a long slender tibiotarsal portion

Euryurus

4. Gonopod with two tibiotarsal branches

Polylepiscus

Gonopod with a single tibiotarsal process

5. Tibiotarsal portion of gonopod broad, short, laminate, solenomerite very short

Tibiotarsus long, slender, usually terete in cross-section, solenomerite typically long

6. Tergites with three transverse rows of large tubercules_-- Protaphelidesmus

Tergites completely smooth____._. Ptyxogon

7. A large ovoid swelling below each antenna

No swellings under the antennae

Pycnotropis

8. Distal end of tibiotarsus of gonopod pointed, or at least unbranched.

9. Tibiotarsus straight or simply curved, parallel sided, distally bifid.

Phinotropis

Distal end of tibiotarsus variously modified 9

Thrinoxethus

Tibiotarsus long and slender, bent into a sigmoid curve, with the terminal end trifid Sigmogonotropis

\section{Family EURYURIDAE Pocock}

Euryurinae Pocock, Biologia Centrali-Americana, Diplopoda, p. 147, 1909.

\section{Genus AMPLINUS Attems}

Pachyurus (Amplinus) Atтems, Denkschr. Akad. Wiss. Wien, vol. 68, p. 281, 1899. (Genotype: Polydesmus klugi Brandt.)

Range.-Mexico (Veracruz and Hidalgo) south to Costa Rica.

Species.-Amplinus abtrusus (Karsch), areatus Pocock, armatus Pocock, crenus Chamberlin, convexus (Carl), erichsoni (Brandt), flavicornis Pocock, klugi (Brandt), manni Chamberlin, niteus Chamberlin, nitidus (Brölemann), orphinus Chamberlin, palicaudatus (Attems), tapachulae Chamberlin, triramus Pocock, vergelanus Chamberlin, and xelitlus Chamberlin.

\section{AMPLINUS FLAVICORNIS Pocock}

Amplinus flavicornis Pocock, Biologia Centrali-Americana, Diplopoda, p. 151, pl. 11, fig. 2, 1909.

Chinapas: Palenque Ruins, near Palenque, July 8, 1949, C. J. Goodnight collector.

This is the first definite locality for the species, which was described from "Central America." The specimens at hand match the original 
description closely. The prozonites are very dark brown, the metazonites light brown or tan; keels, antennae, legs, and last tergite yellow. In the male the apical prongs of the gonopod are not bent to the extent shown in Pocock's figure, but the difference in this respect is hardly significant.

\section{AMPLINUS ORPHINUS Chamberlin}

Amplinus orphinus Chamberin, Proc. U. S. Nat. Mus., vol. 60, art. 8, p. 42, pl. 16, fig. 8, 1922.

British Honduras : Middlesex, February 1, 1923, K. P. Schmidt and L. Walters collectors. A single female tentatively referred to this species (Chicago Natural History Museum).

Guatemala : Chimaltenango, La Jolla Grande (Finca Monserrat), northwest slope of Volcán de Fuego, 5,700 feet, May 3, 1948, R. L. Wenzel and R. D. Mitchell collectors (Chicago Natural History Museum).

Honduras: Río Santa Ana, 2,500 feet, March 21, 1923, Schmidt and Walters collectors (Chicago Natural History Museum).

This species has previously been recorded from La Ceiba, Honduras (the type locality) and Livingston, Guatemala. The following localities represent considerable range extensions for orphinus, which appears to be one of the most abundant and widespread members of the genus. The record from Chimaltenango, Guatemala, is of especial interest in carrying the range up into the high mountains.

\section{Genus AUTURUS Chamberlin}

Auturus Chamberlin, Bull. Univ. Utah, biol. ser., vol. 6, No. 8, p. 7, 1942. (Genotype: Auturus phanus Chamberlin.)

Range.-Eastern United States. Mississippi Valley from Minnesota to Louisiana, east to Georgia.

Species.-Auturus dixianus Chamberlin, evides (Bollman), georgianus Chamberlin, louisianus (Chamberlin), mimetes Chamberlin. phanus Chamberlin, scotius Chamberlin.

\section{Genus EURYURUS Koch}

Euryurus KocH, Krit. Rev. Insectf. Deutschl., vol. 3, p. 59, 1847. (Genotype: Polydesmus erythropygus Brandt.)

Range.--Southeastern United States, north as far as Ohio. Species.-Euryurus australis Bollman, erythropygus (Brandt).

\section{EURYURUS AUSTRALIS Bollman}

Euryurus erythropygus austratis Bollman, Proc. U. S. Nat. Mus., vol. 11, p. 346, 1889.

Euryurus faicipes Loomis, Bull. Mus. Comp. Zool., vol. 92, p. 403, fig. 15, 1943 (type locality: Torreya State Park, Liberty County, Fla.). 
Range.-The species is known to occur from west Florida north through Georgia (Indian Springs), Alabama (Auburn), and Tennessee to extreme northern Kentucky (Crittenden).

Loomis was misled into describing falcipes by a misunderstanding of Bollman's statement that the upper branch of the male gonopod of australis is five times as long as the lower. This refers to the branches in their position on the living animal. In Loomis' description and figure, the gonopod is reoriented so that the actual position is reversed. Bollman's type of australis has been discovered at the National Museum and its gonopods verify this idea, matching perfectly with the figure of falcipes.

\section{Genus PHINOTROPIS Chamberlin}

Phinotropis Chamberlin, Bull. Amer. Mus. Nat. Hist., vol. 78, p. 499, 1941. (Genotype: P. tidus Chamberlin.)

Range.-Northwestern Brazil, northeastern Peru, E'cuador.

Species.-Phinotropis acuticollis (Attems), braueri (Carl), kalonotus (Attems), mammatus (Attems), ?roreri (Chamberlin), tidus Chamberlin.

The original description of Phinotropis is as follows: "This genus is erected for the species described below in which the male gonopods differ from those of Thrinoxethus in having the major distal branch entire and distally acute like the minor branch."

Thrinoxethus was characterized as follows: "Agreeing in general structure with Polylepiscus but differing in the form of the gonopods of the male. In these there are two distal branches of which one is distally acute and the other, larger one, furcate at its distal end . . ."

Insofar as these two diagnoses alone go, it is obvious that Phinotropis is identical with Polylepiscus as used by Attems and others. However, with the restriction of the latter name to Guatemalan species having three terminal processes on the male gonopod, Chamberlin's name becomes available for the South American forms and must be used, although originally a synonym.

Polylepiscus roreri Chamberlin, from Trinidad, is known only from the female type specimen, and probably pertains to another, possibly new, genus.

\section{Genus POLYLEPISCUS Pocock}

Polylepiscus Pocock, Biologia Centrali-Americana, Diplopoda, p. 154, 1909. (Genotype: Polylepiscus stolli Pocock.)

Range.-Guatemala.

Species.-Polylepiscus actaeon Pocock, furcifer Pocock, heterosculptus (Carl), stolli Pocock.

The considerable distance separating the ranges of the Guatemalan and upper Amazonian species hitherto referred to Polylepiscus fur- 
ther serves to emphasize the lack of any close affinity between the two groups.

\section{Genus PROTAPHELIDESMUS Brölemann}

Protaphelidesmus Brölemann, Ann. Soc. Ent. France, vol. 84, p. 559, 1916. (Genotype: Platyrrhacus ligula Brölemann.)

Range.-Venezuela.

Species.-Protaphelidesmus ligula Brölemann, levigatus Attems.

\section{Genus PTYXOGON Chamberlin}

Ptyxogon Chamberlin, Bull. Amer. Mus. Nat. Hist., vol. 78, p. 500, 1941. (Genotype: Ptyxogon incus Chamberlin.)

Range.-Northeastern Peru.

Species.-Ptyxogon incus Chamberlin.

\section{Genus PYCNOTROPIS Carl}

Pycnotropis CARL, Mem. Soc. Sci. Nat. Neuchatel, vol. 5, p. 932, 1914. (Genotype: Polydesmus (Euryurus) taenia Peters.)

Amydrinus Chamberlin, Bull. Amer. Mus. Nat. Hist., vol. 78, p. 500, 1941. (Genotype: Amydrinus pongus Chamberlin.)

Range.-Northeastern Peru, Ecuador, Colombia, Panama.

Species.-Pycnotropis devillei (Silvestri), flavocarinata (Silvestri), haenschi Carl, latzeli Attems, polygonata (Gervais), pongus (Chamberlin), taenia (Peters).

\section{SIGMOGONOTROPIS, new genus}

Genotype.-Sigmogonotropis serratus, new species.

Diagnosis.-Head smooth, clypeal furrow distinct, a prominent ovoid swelling under each antennal socket. Collum and other tergites smooth, underparts without tubercules or bristles. Anal sternite semicircular, without enlarged tubercules. Gonopod of male as follows: Coxa small, without hairs; prefemur and femur coalesced, straight, setose. Distally, set off by a definite constriction, are a long tubular solenomerite and a long, slender, sigmoidally curved tibiotarsus, terminally trifid and with a broad subterminal toothed lamina.

This genus seems to be intermediate between Pycnotropis and Phinotropis.

SIGMOGONOTROPIS SERRATUS, new species

Figure 84

Type specimen.-Male holotype, U.S.N.M. No. 1900, collected at Cana, east Panama, by E. A. Goldman, June 1912.

Diagnosis.-Characterized by the configuration of the male gonopod as represented in figure 84 . 


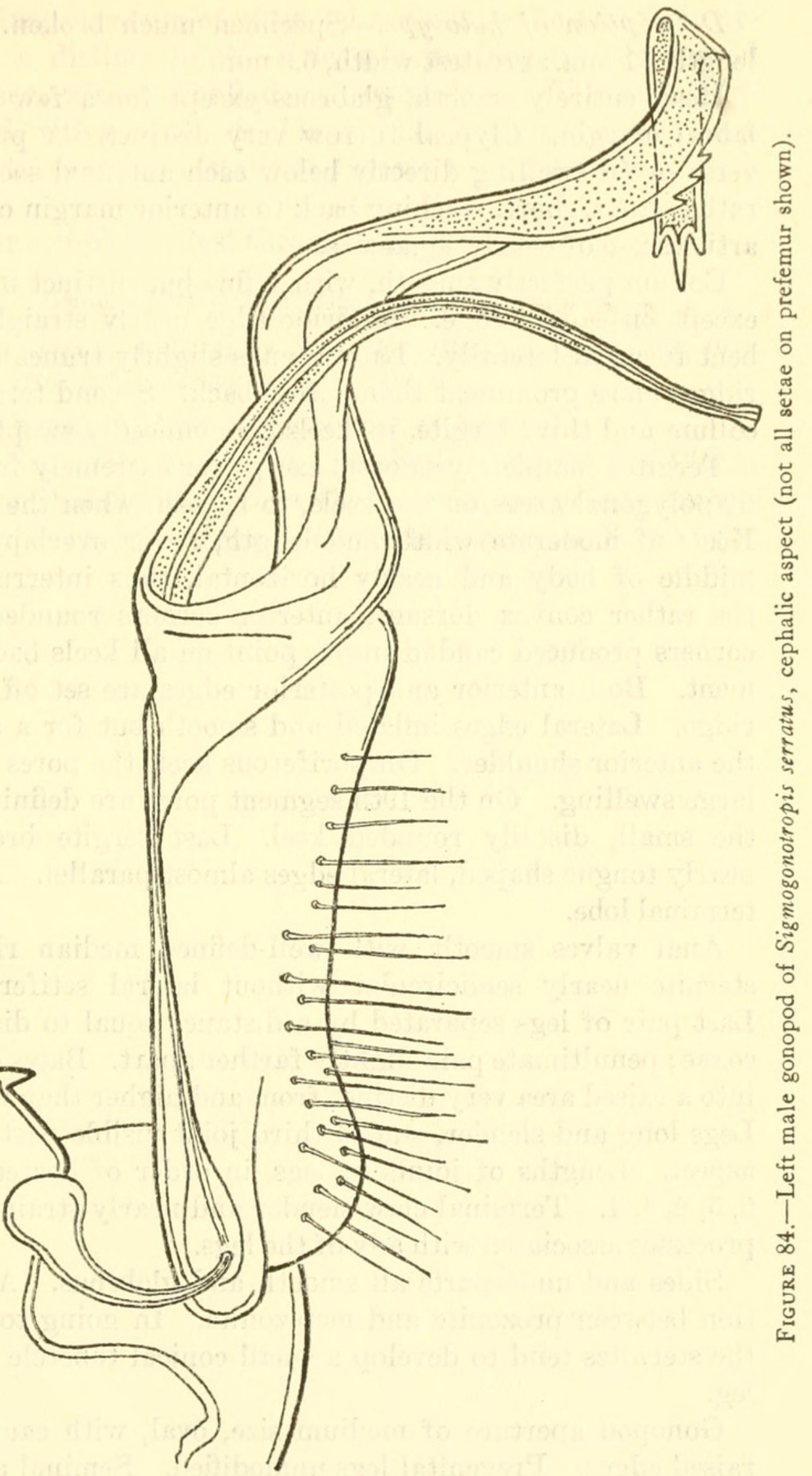


Description of holotype.-Specimen much broken. Approximate length, $51 \mathrm{~mm}$.; greatest width, $6.9 \mathrm{~mm}$.

Head entirely smooth, glabrous except for a few fine hairs near labral margin. Clypeal furrow very distinct. A prominent transverse ovoid swelling directly below each antennal socket. Antennae rather stout, short, reaching back to anterior margin of third tergite; articles $2-6$ of nearly equal size.

Collum perfectly smooth, with a fine but distinct margining ridge except on caudal edge. Anterior edge nearly straight, caudal edge bent forward laterally. Lateral ends slightly truncate and marginal ridges more prominent than across back. Second tergite wider than collum and third tergite, its keels pronouncedly swept forward.

Tergites completely smooth, except for extremely faint suggestions of polygonal areas on the keels, to be seen when the dorsum is dry. Keels of moderate width and length, never overlapping, set above middle of body and nearly horizontal, thus interrupting slope of the rather convex dorsum; anterior corners rounded off, posterior corners produced caudad into a point on all keels back of third segment. Both anterior and posterior edges are set off by a marginal ridge. Lateral edges inflated and smooth but for a slight notch on the anterior shoulder. On poriferous keels the pores are lateral in a large swelling. On the 19th segment pores are definitely inferior on the small, distally rounded keel. Last tergite broadly truncate, nearly tongue shaped, lateral edges almost parallel. A small median terminal lobe.

Anal valves smooth, with well-defined median ridges. Preanal sternite nearly semicircular without lateral setiferous tubercules. Last pair of legs separated by a distance equal to diameter of their coxae; penultimate pair slightly farther apart. Bases of all legs fused into a raised area very distinct from and higher than the prosternites. Legs long and slender, end of third joint visible past keels in dorsal aspect. Lengths of joints of legs, in order of decreasing length, 3, $6,5,2,4,1$. Terminal claw slender and nearly straight. No special processes associated with any of the legs.

Sides and underparts all smooth and glabrous. A deep constriction between prozonite and metazonite. In going toward the head, the sternites tend to develop a small conical tubercle at base of each leg.

Gonopod aperture of medium size, oval, with caudal and lateral raised edges. Pregenital legs unmodified. Seminal apertures small, in end of coxae of second pair of legs, no special processes for them.

Gonopods: Coxa short with a long slender trachial process and a small hook just above exsertion of solenite. Prefemur and femur fused into a straight, heavy, upright trunk, somewhat concave on one side and densely setose; the opposite side is traversed by the seminal 
groove. Terminal elements of gonopod (solenomerite and tibiotarsus) set off by a distinct joint. Solenomerite long, gently curved across tibiotarsus, with a small distal expansion. Tibiotarsus sigmoidally curved, with a subterminal lateral lamination, the outer edge of which bears three teeth; distally trifurcate with the median tooth the longest.

Original color completely lost through preservation.

Genus THRINOXETHUS Chamberlin

Thrinoxethus Chamberlin, Bull. Amer. Mus. Nat. Hist., vol. 78, p. 498, 1941. (Genotype: Thrinoxethus hermosus Chamberlin.)

Range.-Northeastern Peru (Department of Loreto).

Species.-Thrinoxethus bombonus Chamberlin, cainarachus Chamberlin, hermosus Chamberlin, iquitus Chamberlin, lamprus Chamberlin, nitens Chamberlin, phanotypus Chamberlin, ucayalus Chamberlin. 


\section{$2 \mathrm{BHL}$ Biodiversity Heritage Library}

1952. "A new genus of Central American milliped (Family Euryuridae), with notes on the American genera." Proceedings of the United States National Museum 102(3300), 235-243.

https://doi.org/10.5479/si.00963801.102-3300.235.

View This Item Online: $\underline{\text { https://www.biodiversitylibrary.org/item/53447 }}$

DOI: https://doi.org/10.5479/si.00963801.102-3300.235

Permalink: https://www.biodiversitylibrary.org/partpdf/52086

\section{Holding Institution}

Smithsonian Libraries

\section{Sponsored by}

Smithsonian

\section{Copyright \& Reuse}

Copyright Status: Public domain. The BHL considers that this work is no longer under copyright protection.

This document was created from content at the Biodiversity Heritage Library, the world's largest open access digital library for biodiversity literature and archives. Visit BHL at https://www.biodiversitylibrary.org. 